\title{
Assessing and managing the long-term risks and liabilities at a closed Cornish mine used for waste disposal
}

\author{
S.L. Hobbs SKM Enviros, UK
}

\begin{abstract}
During World War II, a large number of new airfields were established across the UK, one of which was at Portreath on the north coast of Cornwall, some $5 \mathrm{~km}$ from the town of Redruth. During the Cold War the site was known as Nancekuke and was used by the Chemical Defence Establishment (CDE) for research and development into chemical warfare agents, with the CDE facility eventually being closed in the late 1970s. When the plant was closed it was fully decontaminated and dismantled, and the wastes were placed in five on-site dumps, two of which were mine shafts associated with Wheal Sally, a former lead and zinc mine also known as Sally's Bottom Mine, which closed in the 1920s.

Assessment of the potential for the waste disposal to impact the environment and cost-effective options for managing this potential commenced in the late 1990s. A comprehensive desk-based evaluation of the mine system was therefore undertaken and an inspection programme formulated, consisting of aboveground drilling and closed-circuit television inspections and belowground inspections, including substantial stabilisation works. In parallel with the inspection, a monitoring programme was formulated to establish water quality conditions and the potential for the wastes to impact them. No significant risk to the environment was identified, but long-term management options were evaluated, including the cost benefit associated with each. The final solution included capping three mine shafts for health and safety reasons, using a bespoke system at one shaft to avoid excavation into wastes, and ongoing monitoring of mine discharge water that is scheduled to continue until 2020 and will then cease if, as is currently the case, no pollution has been identified.
\end{abstract}

\section{Introduction}

The UK has a legacy of mine workings that are hundreds of years old, with mines often abandoned rather than being formally closed and with any closure work being completed in an ad hoc manner and not appropriately documented. Some abandoned mines have no clear owner or mine manager, and there can be challenges around establishing these and any claims to the mineral rights. Risks and liabilities exist from unstable workings and shafts that may be buried and/or inappropriately capped. In addition, the old adage 'out of sight, out of mind' has resulted in shafts sometimes being used for waste disposal, with not all mines or wastes being appropriate for this type of disposal and not often being appropriately documented.

This paper discusses the methodology and findings of the inspection process completed at the former Wheal Sally lead and zinc mine to assess and manage long-term potential risks and liabilities. Particular challenges for the project team, which are detailed in the paper, included:

- Establishing the nature, extent and stability of the mine.

- Determining the type and status of the deposited wastes and managing the potential risk of wastes associated with a former chemical warfare agent facility.

- Operating in a sensitive ecological and archaeological environment.

- Working with a large number of interested parties.

- Collecting sufficient information to assess the risks to the environment in a sufficiently robust manner to meet regulatory requirements. 


\section{$1.1 \quad$ Mine history}

The mine is located on the north coast of Cornwall between the villages of Portreath and Porthtowan, some $5 \mathrm{~km}$ from the town of Redruth (Figure 1). The only known access to the mine is via the adit portal located on a small beach, Sally's Bottom Cove (Plates 1 and 2), within UK Ministry of Defence (MOD) landholdings at RAF Portreath, a former airfield and current radar station.

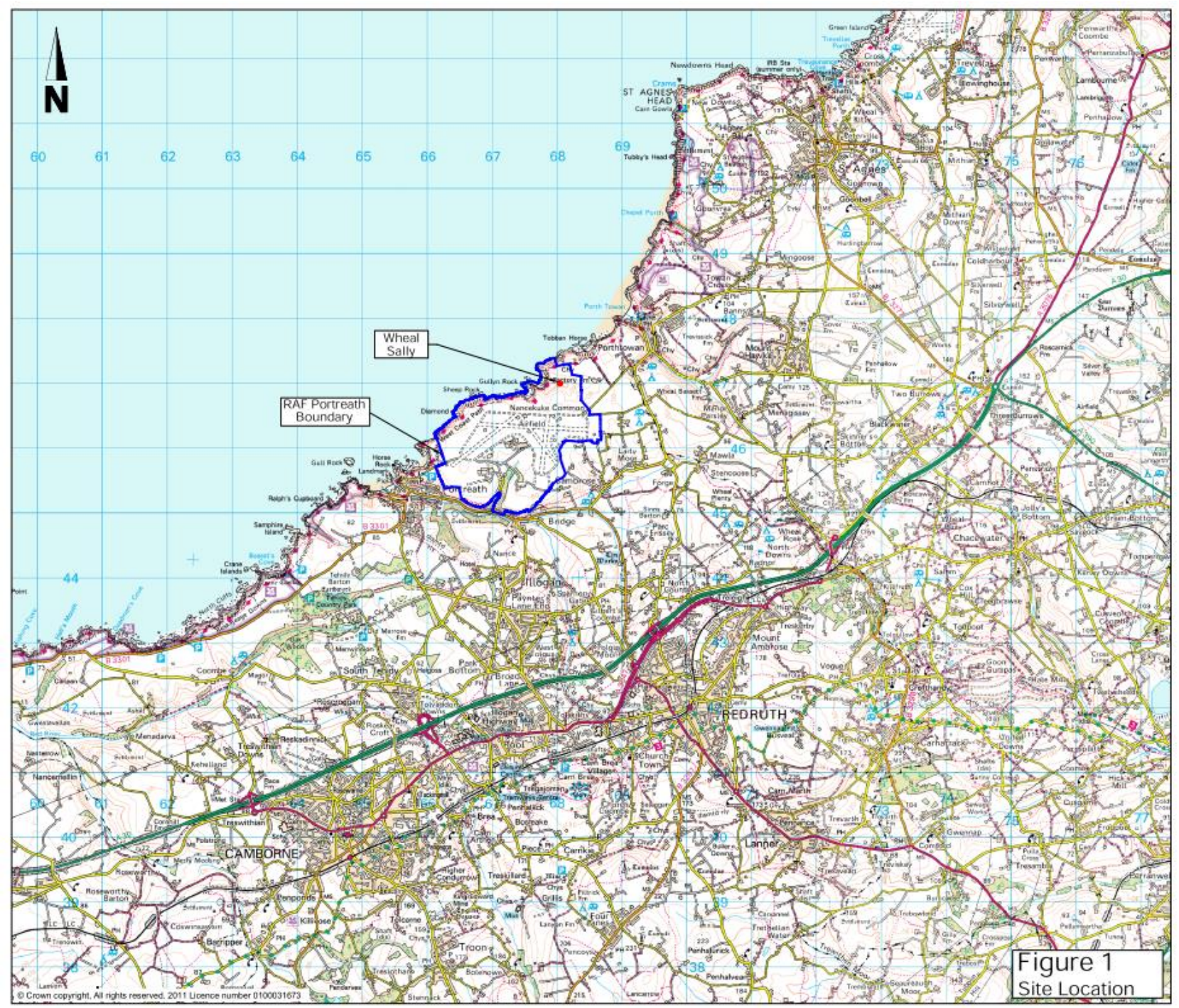

\section{Figure 1 Site location}

It is thought that the mine was not worked prior to the beginning of the nineteenth century (Cornwall County Council, 1998). A mine plan dated 1853 (Cornwall County Archive Department, 1800-1920) shows three shafts in the Wheal Sally area connected to an adit draining water from the mine to the sea at Sally's Bottom Cove. The adit portal is still accessible today (Figures 2 and 3), although this is difficult as it is via a narrow and, in places, sub-vertical path along the cliffs at Sally's Bottom Cove, with the lower part of the path vertical and inundated at high tide. The portal gives access to two passages - a short southeast trending right-hand passage that is open for some $100 \mathrm{~m}$ with no shafts, passages or stopes and the much longer easterly trending left-hand passage that is intersected by a number of shafts and former workings (Figure 4). It is possible that this passage eventually connects into other mine workings associated with the Wheal Sally Incline Shaft, but no documents have been found confirming this, although Dines (1956) confirms that the adit continues inland beyond the shafts. 


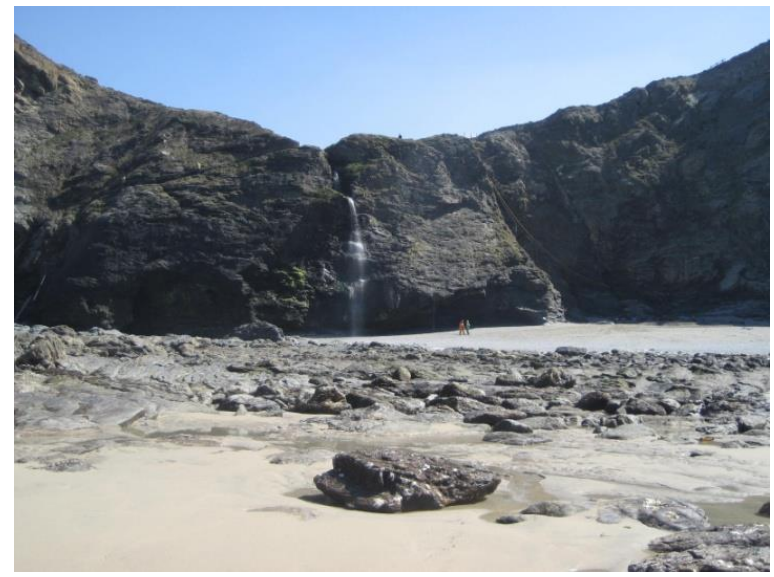

Figure 2 Sally's Bottom Cove with the tide out

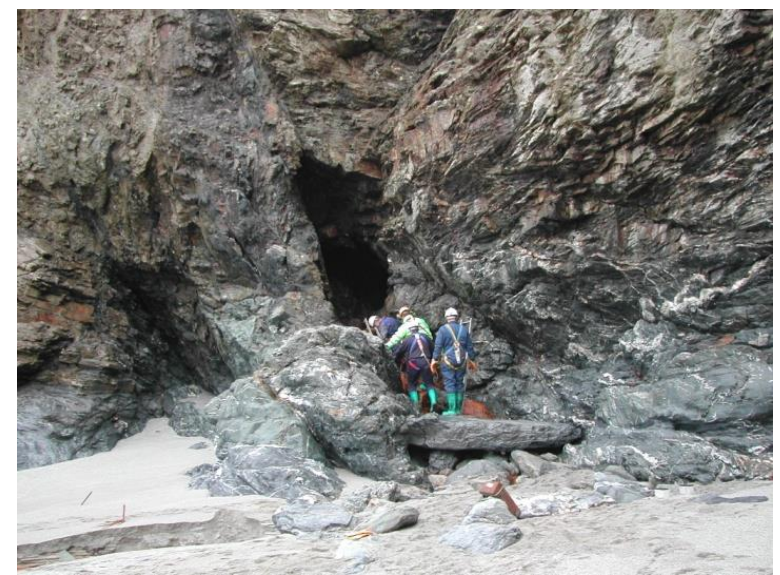

Figure 3 The adit portal is on the right-hand side of the cove

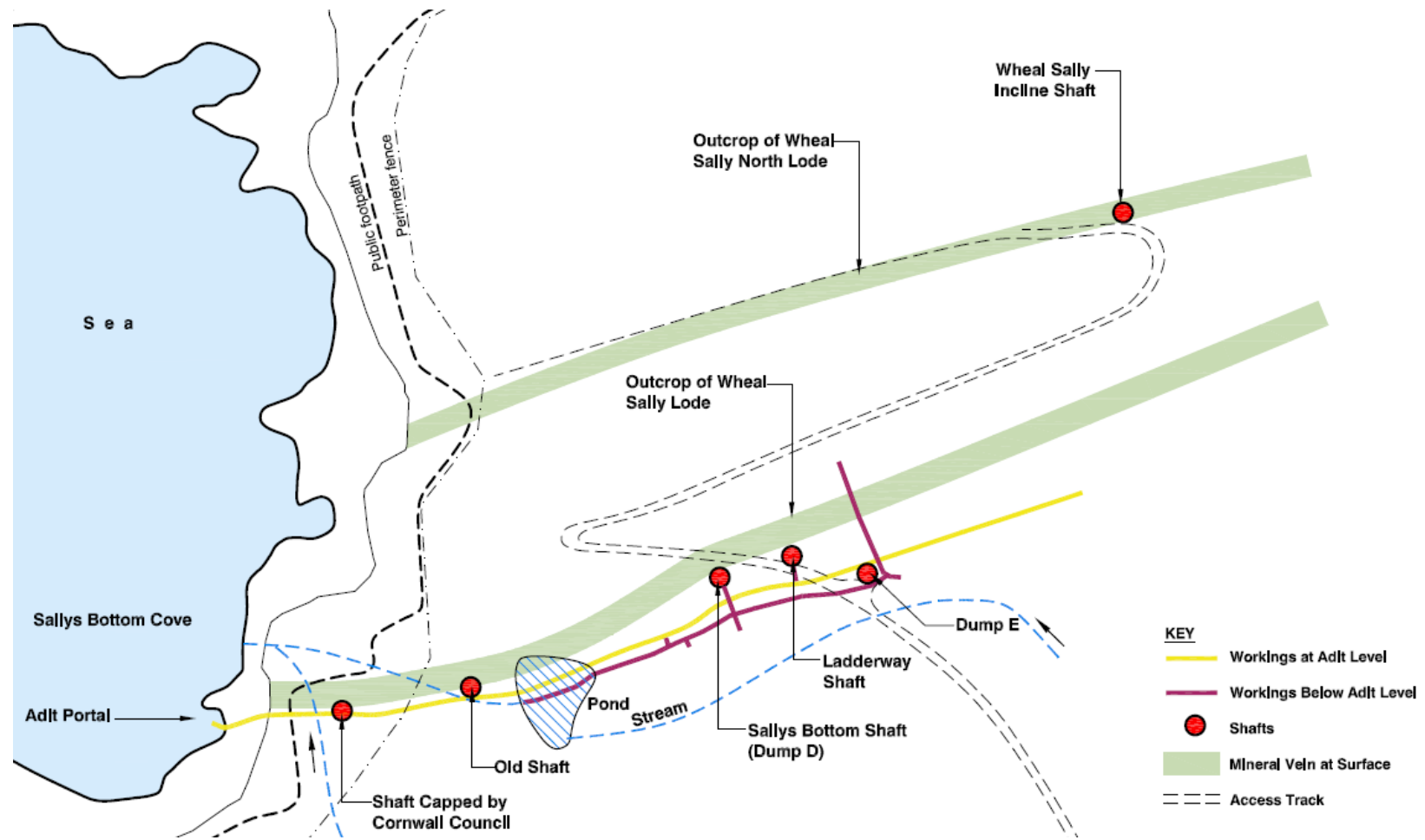

Figure 4 Indicative mine plan derived from historical records (after South West Mining Services) 
Information relating to the early period of mining is limited, with little definitive information known and some confusion caused by the names used and changes in these names. What is known is that in 1862 the mine was some $75 \mathrm{~m}$ deep with at least two working levels below sea level, the deepest some $40 \mathrm{~m}$ below sea level requiring pumping into the drainage adit to keep the workings dry. In the early twentieth century, further prospecting took place, with at least one additional shaft being sunk. The mine is thought to have been abandoned in the mid to late 1920s, with the most recent mine plan dated 1920.

\section{$1.2 \quad$ Military activities}

In 1940 an airfield was constructed at Nancekuke Common on land in proximity to the mine workings, and although there was no construction over the mine, the former workings, including four shafts and the adit portal, were within the curtilage of the airfield. The airfield became known as RAF Portreath and was used throughout World War II, but it was surplus to requirements following the war. It was then selected as the preferred location for research and development facility (Figure 5) into chemical warfare agents, most notably nerve agents. The new plant became known as Chemical Defence Establishment (CDE) Nancekuke and operated throughout the Cold War, finally being closed in 1976.

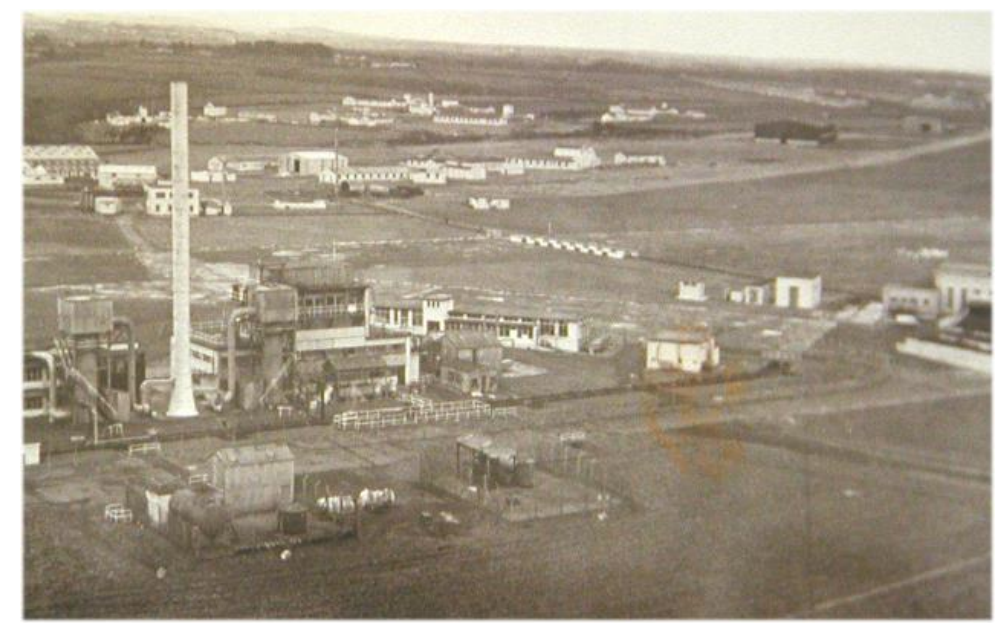

\section{Figure 5 CDE Nancekuke}

When CDE Nancekuke was closed, the facilities were decommissioned, decontaminated and dismantled, and the wastes from this programme were placed in five dump sites within the Ministry of Defence boundary (Chemical Defence Establishment, 1980):

- Dump A - a former quarry some 10-15 m deep.

- Dump B - a land raise of up to $5 \mathrm{~m}$ at the head of a small valley.

- Dump C - a series of small pits excavated into the sub-soil.

- Dumps D and E - former mine shafts.

With the exception of Dump B, it is possible that the dumps were also in use whilst the facility was operational, but there are no details available regarding this.

Following the closure of CDE Nancekuke, the airfield was returned to the RAF and utilised as an emergency landing strip, and it operated as a communications and radar facility.

\subsection{Regulatory drivers}

As part of the UK Ministry of Defence programme of assessing its historical legacy of sites with potential land quality issues, a Phase 1 Land Quality Assessment was completed by the RAF at the site in the late 1990s, including a walkover survey and comprehensive desk-based assessment of the historical use of the site - this identified potential long-term risks and liabilities associated with the dumps at the site (Watson 
et al., 1999). A further driver for the work came in the form of the UK Contaminated Land Regulations 2000, which required the local authority to identify, prioritise and if necessary inspect sites in their area that could be determined as contaminated land, based on various criteria detailed in the regulations. In consultation with the MOD, the five dumps were formally determined as contaminated land under the regulations in 2002, and this required a number of inspections and, if necessary, remediation activities. Much of the remainder of the site is used, and through the history of the site has been used, for agricultural purposes and is uncontaminated.

\section{Methodology}

The work was completed in a phased approach, including the following elements:

- Desk-based assessment, including a review of historical information regarding the operation and dismantling of CDE Nancekuke, mining records including those held by Camborne School of Mines and a review of general environmental data held by the Environment Agency, British Geological Survey, Natural England etc.

- Formulation of a conceptual site model identifying potential contaminant sources, pathways and receptors that could result in risks to human health, property and the environment.

- Appointment of a mine manager and mine engineer, clarification of mine ownership issues and preparation of health and safety documentation.

- Improvements to the miners' travelling way to allow safe access to the adit for inspection.

- The use of geophysical methods to locate a shaft that was not open at the surface.

- Partial excavation of two shafts and one suspected shaft.

- Borehole drilling into the shafts, with subsequent downhole closed-circuit television (CCTV) inspection.

- Stabilisation of the adit to allow safe access for inspection.

- Collection of soil and water samples for laboratory analysis.

In addition, the whole project included extensive liaison with a large number of stakeholders, including the Environment Agency, district and county councils, local residents and other interested parties. In particular, the documentary evidence required to meet the requirements of the Contaminated Land Regulations was agreed with the Environment Agency, in addition to the monitoring necessary to demonstrate that these criteria had been met.

\section{$3 \quad$ Findings of the assessment}

\subsection{Desk-based assessment}

The desk-based assessment indicated that there were originally four shafts that all penetrated the Wheal Sally adit, which drained to the sea (see Figure 4). The adit is known to extend inwards by at least $90 \mathrm{~m}$ beyond the furthest of the four shafts inspected and may potentially connect to further workings and other shafts located within the site, but these did not form part of this inspection. The first of the four shafts in from the adit portal is located alongside a public footpath. For safety reasons, this shaft was capped by Cornwall County Council in the 1970s. The location of the second shaft was known from site plans and historical maps, but there was no surface expression of it and no information was available regarding if, how or when it was capped. The location of the third and fourth shafts was thought to be well known, based on areas that had been fenced by MOD in the 1980s and demarcated on-site as Dump areas D and E.

Dump D was at the location of Sally's Bottom Shaft (Figure 6), a relatively small shaft (c. $2.1 \times 1.5 \mathrm{~m}$ ) and possibly partly cased with timber and used for pumping water from the lower levels and for skip hoisting 
etc. It is likely that any timber casing was left in-situ when the mine was abandoned, and this is likely to be in very poor condition. The shaft is thought to be vertical only for its upper $7 \mathrm{~m}$, with the remainder of its $78 \mathrm{~m}$ total depth dipping at $65-70^{\circ}$ following the mineral lode.

Dump E was not at the location of a shaft denoted on any mine plans, but there was a shaft denoted some $20 \mathrm{~m}$ away, designated on plans as the Ladderway Shaft. As the mapping had been completed in the 1920s, initial thoughts were that the mapping was incorrect, although discussions with local miners suggested that the potential for this was low, and site investigation commenced (see below). The Ladderway Shaft is described in historical documents as being smaller than Sally's Bottom Shaft (c. $1.8 \times 1.2 \mathrm{~m}$ ) and vertical for some $15 \mathrm{~m}$, with a $2 \mathrm{~m}$ horizontal leg followed by a c. $12 \mathrm{~m}$ sub-vertical drop into the adit. The Ladderway Shaft is thought to continue into the lower two levels via an offset section, with its total depth being some $78 \mathrm{~m}$.

The geology at the site is Devonian rocks of the Porthtowan formation, which comprise an interbedded sequence of shales and slates, with thin units of coarse-grained sandstones present throughout the formation (Leveridge et al., 1990). Late Carboniferous granitic intrusions are present in central Cornwall, and the surrounding rocks have been subjected to low-grade regional metamorphism, and associated mineralisation of the surrounding country rock has occurred. This mineralisation tends to consist of tin ores close to the granitic bodies, with zinc, lead and copper ores being found on the periphery of the mineralised area, including at Wheal Sally.

The desk-based assessment also confirmed that the mine is located in a sensitive ecological environment the Godrevy Head to St Agnes Site of Special Scientific Interest (SSSI), which was designated for its maritime heathland and grassland and its inter-tidal shoreline (MAGIC, 2013). The mine is also in an area that at the time was proposed (and is now designated) as a World Heritage Site on the basis of its mining history and features of archaeological interest. The assessment also identified a report regarding water sampling that was completed by the environmental regulator in the early 1990s and a number of useful military documents, a key one of which on the closure of CDE Nancekuke was classified as top-secret, although this report has subsequently been declassified and has been relied on for part of the work completed.

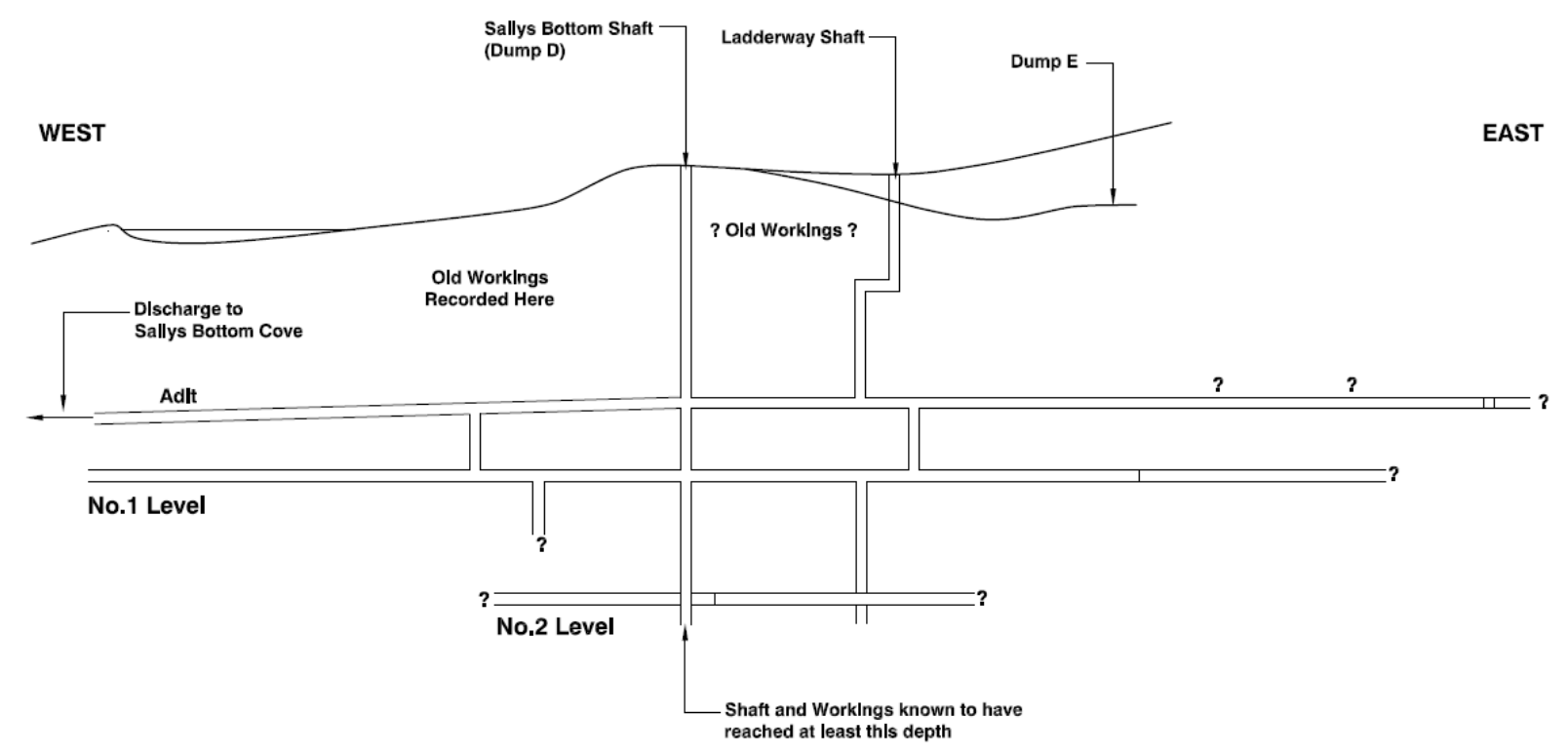

NOT TO SCALE

\section{Figure 6 Indicative mine cross section derived from historical records (after South West Mining Services)}

The desk-based assessment reviewed all available MOD reports regarding the waste disposal operations, and a list of possible materials that were dumped was formulated and used to identify potential contaminants. The materials reported as dumped included former reaction vessels, motors, pumping lines 
and demolition material from fume cupboards etc., as well as anecdotal evidence to suggest that wastes from the former Motor Transport section were included. This indicated that a mixture of disused and decontaminated plant and materials had been placed in the shafts, but there was no evidence indicating that the shafts had been used for disposing of chemicals. The concerns were therefore that there could be chemical residues on some of this equipment, and a list of chemicals that could potentially be present was formulated and a preliminary risk assessment was prepared. The primary receptors of concern that were identified by the risk assessment were humans on- and off-site, flora and fauna in the SSSI and groundwater, with surface water as a secondary receptor. Site investigations were then designed to assess these risks.

\subsection{Investigation of the shafts}

Before any investigation of the shafts or adit inspection could be undertaken, it was necessary to gain assent from Natural England for certain aspects of the inspection, as the mine is located within an SSSI. This required a bat survey using detectors connected to automatic data loggers at the adit portal to check for use of the mine as a bat roost, but no bats were identified as using the mine - it is thought that this is largely due to the very wet nature of the mine and, as was subsequently found, a blockage only $50 \mathrm{~m}$ inside the portal. All of the aboveground works with potential to impact on the SSSI also needed assent, and working closely with the Natural England officer responsible for the area ensured that the works progressed smoothly and, where necessary, that appropriate mitigating activities were completed.

As indicated above, one of the four shafts had been capped relatively recently, and its location was well established, so further assessment of this was not required. The location of the second shaft was not known exactly, and so a geophysical investigation was undertaken to identify its location. No clear or obvious geophysical signature was identified, but several potential locations were identified, and subsequent excavation confirmed the presence of a relatively small diameter $(<1 \mathrm{~m})$ shaft plugged with earth and buried some $5 \mathrm{~m}$ below loose soil cover. This shaft was never used for waste disposal and for safety reasons was filled with a concrete plug and reburied by the MOD, and the area was reinstated to heathland.

The third shaft is Dump D, which is at the location of Sally's Bottom shaft. This shaft is known to have been used for waste disposal by the MOD, with a mixture of wastes reportedly disposed, including general wastes and equipment. The wastes in the shaft were thought to be covered by several metres of earth. Two approaches were adopted to investigate the shaft: angled borehole drilling into the waste deposits and direct inspection of the lower end of the shaft via access along the adit (Enviros, 2007). Based on measurements from historical mine plans, a borehole was drilled into the angled shaft, which was intersected on the second attempt (Figures 7 and 8). A CCTV camera was lowered into the borehole, and several plastic bags and other items of waste could be seen. There were only very small spaces evident, and it was clear that waste infilling had taken place. The borehole entry point into the shaft was approximately half the distance between ground level and the adit. There was no evidence of any waste at the surface with the only demarcation of the dump being a plastic fence and small concrete marker posts (Figure 9).

In order to determine if the Ladderway Shaft was present at the area designated as Dump E or at the location shown on the historical mine plans, the location shown on the mine plan was surveyed and excavated. This revealed a rectangular shaft cut into bedrock approximately $1 \times 1.5 \mathrm{~m}$, which was encountered less than $1 \mathrm{~m}$ below ground level (Figure 9(b)). The top $3 \mathrm{~m}$ of the shaft was backfilled with compacted rock mine waste, below which MOD wastes, including large chemical mixing vessels, were encountered. These were reported to have been decontaminated prior to deposition. A team dressed in full NBC (nuclear, biological, chemical) suits and wearing respirators was used to collect a small number of soil samples from inside near-surface mixing vessels and surrounding rock waste, the laboratory results from which confirmed that they had been decontaminated. Upon completion of the work, the shaft was backfilled with the arisings and the areas marked by a fence. At the end of all the site works at RAF Portreath, the shaft was covered with a robust concrete cap for health and safety reasons. 
One question remained regarding waste disposal in the Ladderway Shaft and that was the depth of disposal - was it just the upper $15 \mathrm{~m}$ vertical shaft? Or did the waste disposal also extend into the offset lower section of the shaft below the horizontal leg? In order to answer this question, a vertical borehole was drilled above the surveyed position of the lower vertical section of shaft and a CCTV survey was completed. This proved that the wastes were limited to the upper $15 \mathrm{~m}$ section of shaft and that the lower c.12 $\mathrm{m}$ was open to the adit.

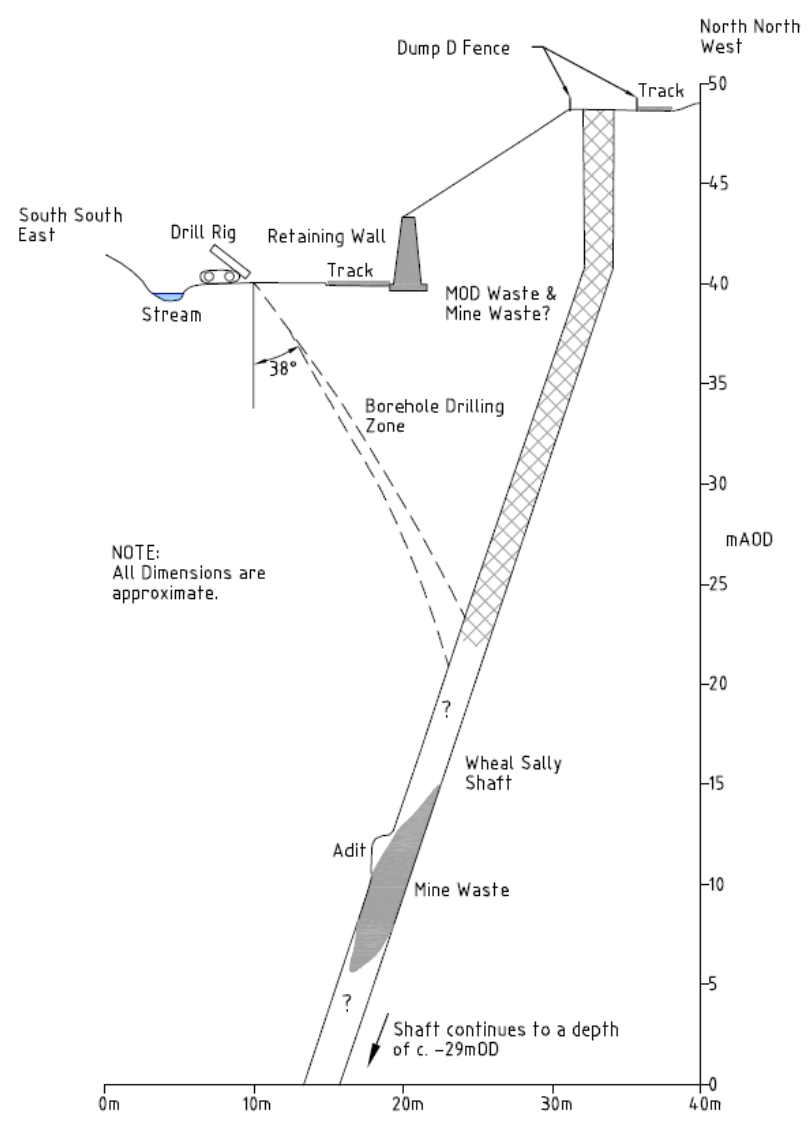

Figure 7 Angled borehole drilling at Dump D

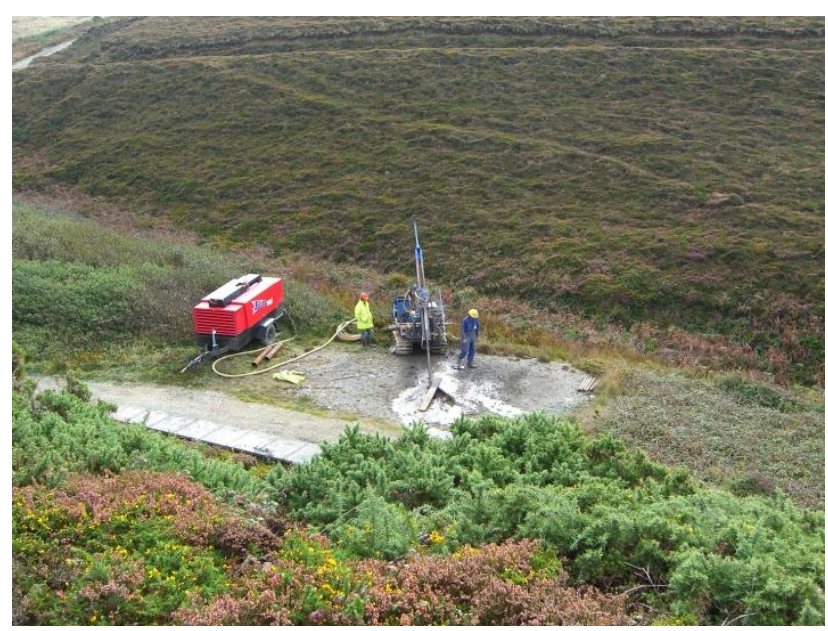

\section{Figure 8 Looking from Dump D towards the drill rig}

The presence of the Ladderway Shaft raised the question as to what was at the location fenced and marked as Dump E. Investigations into this area identified a small soil-covered concrete pad that had been cast directly onto bedrock, with no underlying shaft. The pad had likely been cast as a plinth on which to mount a pump as part of works undertaken sometime between 1940 and 1960 to construct a pond (possibly used 
for water supply) in the valley where the mine is located. It subsequently came to light that the dump areas had been fenced several years after CDE Nancekuke had closed, with the fencing undertaken by a different team to that involved in the closure process. It is also likely that the Ladderway Shaft had been infilled whilst CDE Nancekuke was operational, not at closure, and this resulted in the location of the former shaft becoming vegetated and not being clear, such that the wrong area was fenced. The excavation did confirm the accuracy of surveying carried out in the 1920s.
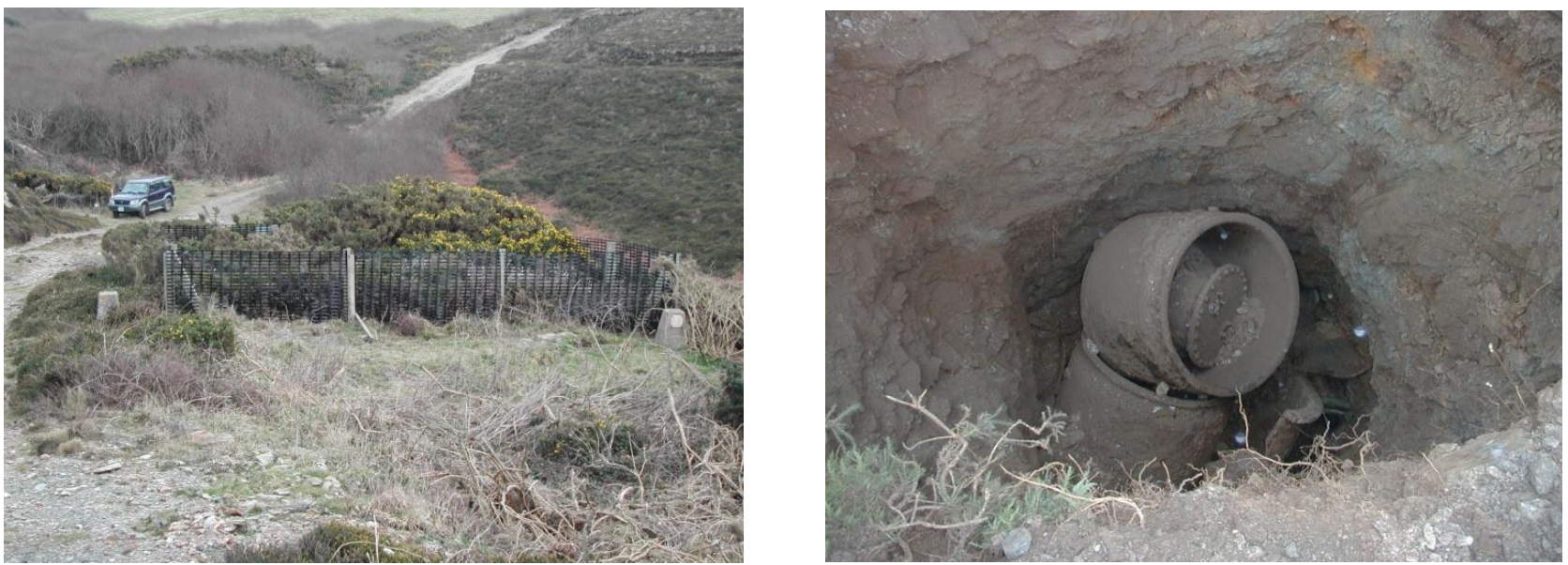

Figure 9 (a) Dump D (fenced area); and (b) excavation of the Ladderway Shaft

\subsection{Adit inspection}

In order to inspect the adit to confirm whether any wastes were present and to assess water migration routes, the adit was entered. Due to the nature of the wastes and the mine, this involved complex health and safety and emergency response planning, with a significant amount of cross-training between chemical warfare agent specialists at the Defence Science Technology Laboratory, Cornish mining experts and SKM Enviros staff.

The mine adit was entered by a mixed team of specialists, but progress was limited by areas of collapse and instability. A series of engineering trips were therefore made into the mine to undertake stabilisation works (Figure 10), to place access walkways across winzes and flooded shafts, to place protection in places in the roof of the adit passage that had been worked and to drain areas where water was backed up behind collapses in the adit. As part of this work, a stream at the surface was diverted into a series of pipes, as it was thought that some of this water was entering the workings and had the potential to cause instability. As this work was in the SSSI, it required assent from Natural England and a Land Drainage Consent from the Environment Agency.

In addition, the adit was gated to control access both during and on completion of stabilisation works, especially as the stabilisation works were temporary and they only progressed as far as the Ladderway Shaft and not further into the mine.

The inspection confirmed that there was a reasonably consistent water flow along the adit, with substantial sediment in places, including iron ochre deposits (Enviros, 2007). The water flow reduced markedly and disappeared towards the base of the two waste-filled shafts. The base of Dump D was clear of MOD waste deposits, and although the shaft used to continue beneath the adit, it was filled with mine wastes (Figure 11), although the stability was questionable and a temporary access was installed over the lower shaft. The shaft looking upwards to Dump D was open for at least $6 \mathrm{~m}$, with partial blockage by rock and soil mine wastes. Samples of this material were taken, but no contaminants that might be expected in MOD wastes were identified. No significant amount of water was identified as flowing down the shaft at adit level. The adit inspection also confirmed the findings of the CCTV survey that the base of the Ladderway Shaft was clear of MOD wastes. 


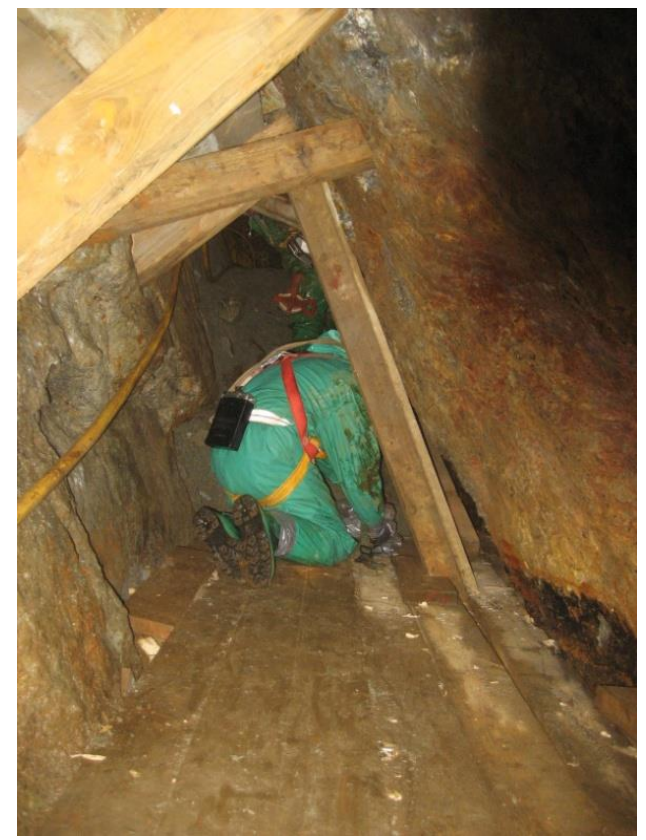

\section{Figure 10 Stabilisation works above a winze}

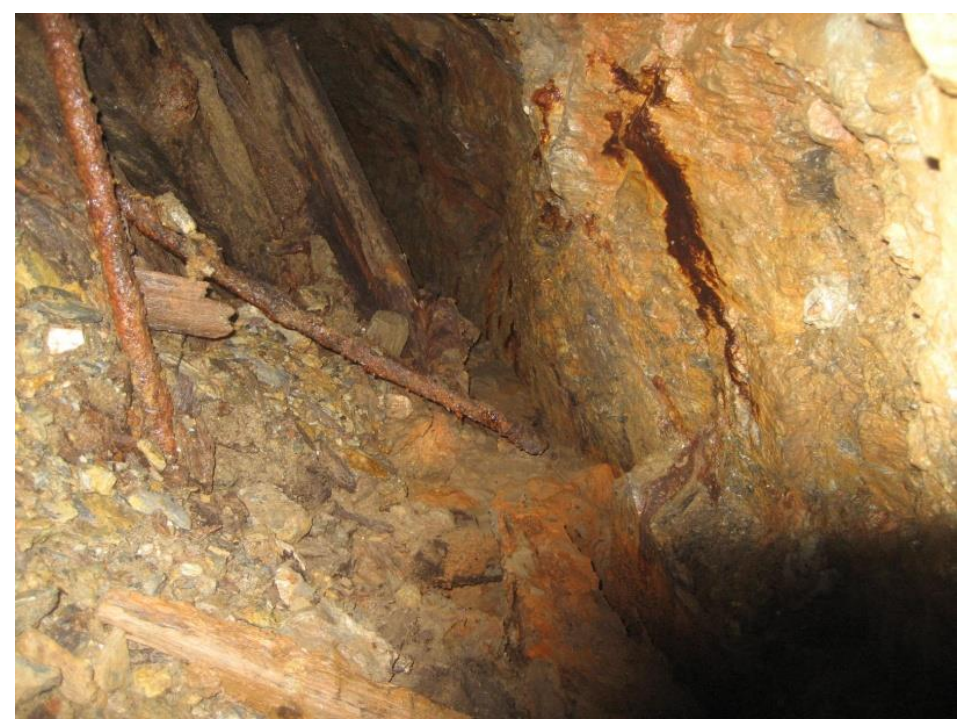

\section{Figure 11 Mine waste at adit level at the base of Dump D}

\subsection{Water sampling and analysis}

The first documented water sampling from streams and adits along the coast at RAF Portreath was completed by the National Rivers Authority (NRA, 1992). When the investigation works at Portreath commenced in 2001, a monitoring regime was implemented to collect samples of the adit water in addition to groundwater samples collected from a shallow and a deep borehole drilled into the ground in the valley where the mine was located. Laboratory analysis was undertaken for a range of substances, including metals, petroleum hydrocarbons, polycyclic aromatic hydrocarbons, volatile organic compounds (VOCs), semi-volatile organic compounds (SVOCs) and mustard agent and its breakdown products. The programme included sampling at frequencies between quarterly and six-monthly.

The samples were taken from the adit water discharging from Wheal Sally. This task was complicated by the fact that rope access was required due to the poor condition, the very steep and exposed nature of the former miners' travelling way and the access limitations imposed by the tides. Even once the travelling way was improved to allow the mine inspection to take place, access for sampling was limited, and the safety 
systems were removed following completion of the inspection to deter future access to the adit and to remove liability for long-term maintenance. Sampling was initially quite constrained and limited to quarterly samples. Once the inspection was completed, a borehole was drilled into the adit (Figure 12(a)) and a small sump was constructed in the floor of the adit - this allowed sampling to be safely completed from the ground surface without rope access. The results of all of the sampling are provided in the monitoring reports (SKM Enviros, 2011: CD1, Report Library, Enviros Reports, Monitoring), with the data from the recent sampling summarised in Table 1 . The results confirm that some metals, particularly zinc, are elevated and associated with the mineralisation, but no traces of chemical warfare agents, related contaminants or organic compounds (with the one very minor exception listed in Table 1) have been detected in the water.

Table 1 Summary of recent water monitoring at the adit (all values in $\mu \mathrm{g} / \mathrm{l}$ )

\begin{tabular}{|c|c|c|c|c|c|c|c|c|}
\hline Determinand & Jun-10 & Sep-10 & Dec-10 & Mar-11 & Sep-11 & Feb-12 & Sep-12 & Feb-13 \\
\hline Mustard agent & $<$ LOD & $<$ LOD & $<$ LOD & $<$ LOD & $<$ LOD & $<$ LOD & $<$ LOD & $<$ LOD \\
\hline $\begin{array}{c}\text { Mustard agent } \\
\text { breakdown products }\end{array}$ & $<L O D$ & $<$ LOD & $<L O D$ & $<$ LOD & $<L O D$ & $<L O D$ & $<$ LOD & $<$ LOD \\
\hline Arsenic & $<1$ & 1.1 & $<1$ & 4.3 & $<1$ & $<1$ & 1.6 & $<1$ \\
\hline Boron & 840 & 35 & 23 & 78 & 43 & 240 & 850 & $<20$ \\
\hline Copper & 6 & 3.3 & 1.8 & 14 & 3.4 & 2.7 & 3.2 & 25 \\
\hline Lead & 3.1 & 12 & $<1$ & 120 & 2.4 & 4.1 & 33 & 2.6 \\
\hline Cadmium & 2.4 & 2.5 & 1.8 & 3.2 & 2 & 2.2 & 1.9 & 2 \\
\hline Chromium & $<1$ & 6.7 & 4.1 & 8.9 & 2.1 & 3.6 & 2.2 & 6.3 \\
\hline Ammoniacal Nitrogen & 520 & 70 & $<10$ & 180 & $<10$ & 80 & $<10$ & 80 \\
\hline Manganese & 780 & - & 420 & 590 & 780 & 660 & 590 & 530 \\
\hline Mercury & 0.011 & $<0.01$ & $<0.01$ & $<0.01$ & 0.08 & $<0.01$ & $<0.01$ & $<0.01$ \\
\hline Nickel & 13 & 17 & 12 & 16 & 14 & $<1.0$ & 12 & 11 \\
\hline Selenium & 2.1 & 2.1 & 1.3 & 1.4 & 4 & 3.1 & 1.4 & 1.1 \\
\hline Zinc & 1600 & 1900 & 1100 & 1700 & 1400 & 1500 & 1600 & 1200 \\
\hline Total PAH & $<0.2$ & $<2$ & $<0.2$ & $<0.2$ & $<0.2$ & $<0.2$ & $<2$ & $<2$ \\
\hline $\begin{array}{l}\text { Total Petroleum } \\
\text { Hydrocarbons (TPH) }\end{array}$ & $<10$ & $<10$ & $<10$ & $<10$ & $<10$ & $<10$ & $<10$ & $<10$ \\
\hline VOCs & $<L O D$ & $<$ LOD & $<$ LOD & $<$ LOD & $<$ LOD & $<L O D$ & $<$ LOD & $<$ LOD \\
\hline SVOCs & $<$ LOD & $<\mathrm{LOD}$ & $<\mathrm{LOD}$ & $<$ LOD & $<$ LOD* $^{*}$ & $<$ LOD & $<\mathrm{LOD}$ & $<$ LOD \\
\hline
\end{tabular}

Notes: LOD - limit of detection, *One SVOC identified - 2, 6-Dinitrotoluene, but at a very low concentration: $0.57 \mu \mathrm{g} / \mathrm{l}$, just greater than the LOD of $0.5 \mu \mathrm{g} / \mathrm{l}$ 

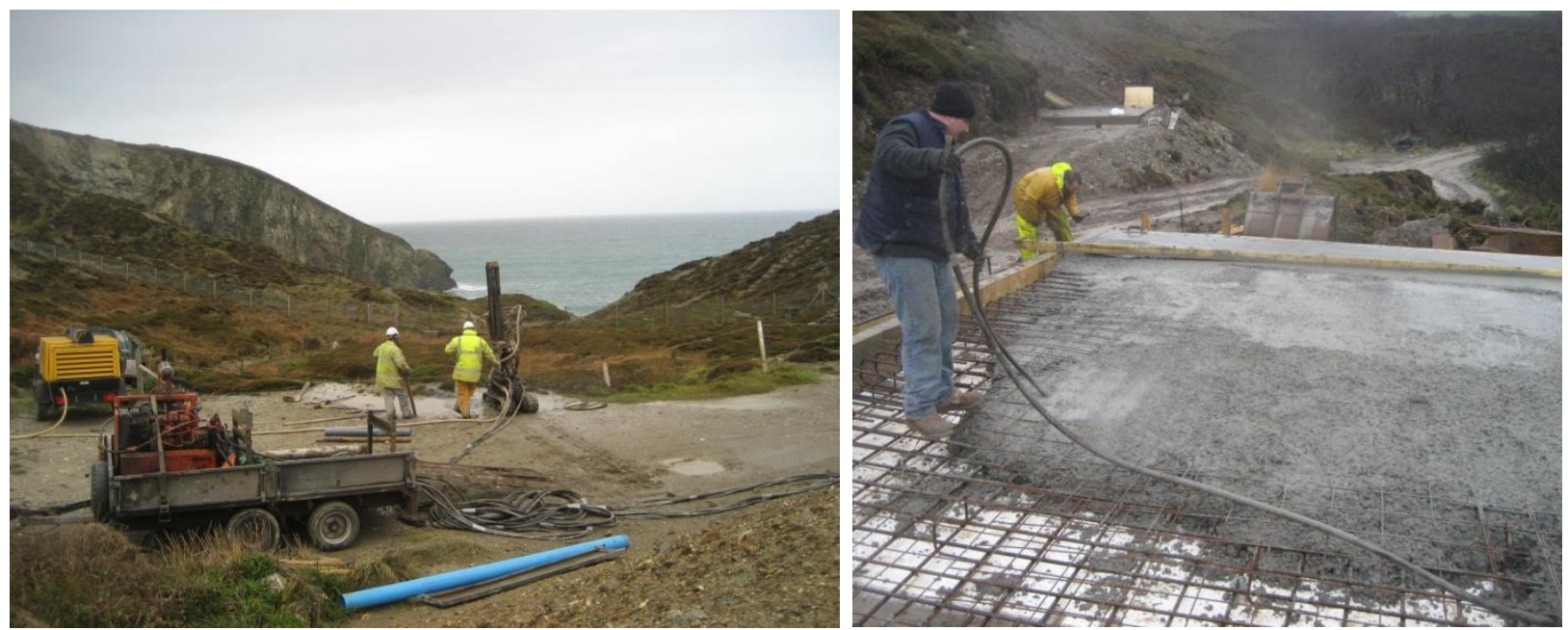

Figure 12 (a) Drilling into the adit to allow water sampling; and (b) shaft capping at Dump D - the cap at Ladderway Shaft is in the background

\subsection{Remedial options and reporting}

All of the work completed was comprehensively documented (SKM Enviros, 2011) to provide a robust audit trail describing the data that were collected, formulation of conceptual models of the mine and its environs, possible contaminants, how they could move and what they could impact. The reports also detailed the inspection process and procedures used and reviewed the risks and liabilities posed. The assessment concluded that no current harm had been caused to sensitive receptors and no pollution had been identified associated with the deposited MOD wastes. However, there was the potential for future pollution and/or harm, but the potential for this was assessed as low. For this reason a remediation options appraisal was completed that assessed possible actions that could be taken to reduce the risks, considering the practicability, effectiveness, durability and reasonableness of completing these in addition to the potential level of seriousness of pollution or harm that could occur.

The remedial options that were considered included excavation of the wastes by quarrying or mining, capping the shafts and grouting the wastes in-situ, in addition to further investigation and monitoring to better define the risks (Enviros, 2009). Each option was considered against a series of criteria, and a scoring matrix was prepared to identify the preferred option, which was grouting in-situ. This option was then further assessed to determine if it was 'reasonable' (as defined in the Contaminated Land Statutory Guidance at the time), and it was determined that the cost of remediation was not commensurate with the low level of risk to the environment and human health. It was determined therefore that a further 10-year period of monitoring (to 2020) should be undertaken to confirm the status of the water quality at the site this would result in data for a period at least 50 years after waste disposal. This solution has been accepted by the County Council, Environment Agency, Natural England and other local stakeholders.

In addition to the contaminated land elements of the waste disposal operations completed at the mine, the implications of the health and safety of having three shafts on-site that had not had engineered caps installed remained an issue. Bespoke designs were therefore prepared for the three dumps, and the caps were installed. At Dump D, a key consideration was cap emplacement without disturbing the wastes - this involved identification of the shaft boundaries, excavation of trenches into bedrock and casting loadbearing foundations such that the cap could be laid over the dump without bearing on the wastes (Figure 12(b)). The caps were all landscaped to blend into the environment, and the land was returned to its precapping condition within the SSSI and World Heritage site.

All of the works that were completed are fully detailed so that in another 100 years, if someone asks a question about the mine or considers reopening it, the information will be readily available (SKM Enviros, 2011). The reports have all been provided to Cornwall Council and the Environment Agency, and copies are held by the Ministry of Defence estates management and by the RAF as site operator. One of the final 
documents included in the reports is the mine abandonment plan that was submitted to the Health and Safety Executive (Mines Inspectorate) at completion of the works (SKM Enviros, 2011: CD2, Wheal Sally Mine).

\section{Conclusions}

The assessment of risks and liabilities at Portreath identified a number of issues associated with mine closure that may be pertinent to consider at other sites:

- The nature of the backfilling of former mineshafts in Cornwall is very variable and can result in a range of environmental, health and safety risks that pose a potential liability for landowners and operators. Assessment of these risks and liabilities can be an expensive and time-consuming process, and the work undertaken should be commensurate with the degree of risk posed.

- Identification of key issues at the desk-based assessment stage is critical, along with early engagement with key stakeholders to ensure that the works progress in a smooth and timely manner and to ensure key considerations (e.g., ecological status) are not overlooked.

- There are good sources of information available that can be used to provide details of historical activities, although there can be confusion regarding site names, and not all of the information is necessarily accurate - understanding how, when and why a document was produced can help to identify some of these issues. Ideally multiple sources of information should be used to draw out 'lines of evidence' that confirm the understanding of a site's history and operation.

- Even shafts close to one another in the same mine can be of a very different nature and can have a different history and liability profile, and each should be assessed independently. At Wheal Sally, each of the four shafts was of a different construction and depth and had been infilled / capped in a very different manner.

- A number of above- and belowground techniques can be used to ensure that an appropriate inspection can be completed - reliance should not be placed on a single technique.

- Robust and comprehensive documentation that can be provided to regulatory authorities and local stakeholders is an important and often overlooked part of the closure process.

- The costs of planning for closure and implementing and documenting an appropriate mine closure plan are substantially less than the costs of revisiting a closed mine many years in the future to deal with the uncertainty and potential risks. In addition, a well-thought-out and managed plan can markedly reduce long-term corporate liability.

\section{Acknowledgements}

This paper has been based on work completed by SKM Enviros (and others) for the UK Ministry of Defence, and their permission to use the information for this paper is greatly appreciated. Two of the drawings and one photograph have been modified from those provided by South West Mining Services.

\section{References}

Chemical Defence Establishment (1980) Closure of CDE Nancekuke, Technical Memorandum No. 8, available in SKM, 2011. Cornwall County Council (1998) Report to Kerrier District Council Shaft Capping Contract 11, Archaeological Assessment. Cornwall County Council Archive Department (various dates circa 1800-1920) Abandoned mine plans MRO 200, 202C, DDX 560/29 and DDM172.

Dines, H.G. (1956) The Metalliferous Mining Region of South-West England, Memoir of the Geological Survey of Great Britain. Enviros (2007) RAF Portreath Part 2A Voluntary Inspection, Wheal Sally Mine Adit Inspection - Final, Prepared for Defence Estates, Project No. 11774, available in SKM, 2011.

Enviros (2009) RAF Portreath Part 2A Voluntary Inspection, Dump D and the Ladderway Shaft Remedial Options Study - Final, Prepared for Defence Estates, Project No. 11774, available in SKM, 2011. 
Leveridge, B.E., Holder, M.T. and Goode, A.J.J. (1990) Geology of the Country around Falmouth, Memoir for 1:50,000 Geological Sheet 352 (England and Wales), HMSO, London.

MAGIC (Multi-Agency Geographic Information for the Countryside) (2013) viewed 31 July, http://magic.defra.gov.uk.

NRA (National Rivers Authority) (1992) Water Quality Investigations at Nancekuke, Cornwall, Ref:WQP/92/002, available in SKM, 2011.

SKM Enviros (2011) RAF Portreath Closure Report, prepared for Defence Estates, Project No. 11774, available via Cornwall Council and the Environment Agency (Exeter).

Watson, A.J., Farmer, T.P. and Court, M.E. (1999) RAF Portreath Land Quality Assessment, Phase 1 - Desk Study, available in SKM, 2011. 